\title{
The Discourse on Legal Utopia for The People with Disabilities in Order to Remove the Educational Segregation
}

\author{
Zamroni Abdussamad ${ }^{1}$ \\ ${ }^{1}$ Faculty of Law, Universitas Negeri Gorontalo, Indonesia. E-mail: zamroni@ung.ac.id
}

\section{Article Info}

\section{Keywords:}

Persons with Disabilities;

Segregation; Education

How to cite (APA Citation Style):

Abdussamad, Z. (2021). "The Discourse of Utopia Is the Law of Persons with Disabilities in Order the Removal of Segregation Education". Jambura Law Review. JALREV 3 (2): 378-394

\begin{abstract}
The right to education for persons with disabilities is still a contemporary legal issue with legal and social problems. The laws and regulations governing the right to education with disabilities are still segregated for the research objectives, namely the Pattern of analyzing the educational arrangements for persons with disabilities and the ideal arrangements for achieving equality in education for persons with disabilities in Indonesia. This research method is categorized into normative legal research types. It is based on the issues and or themes raised as research topics using a philosophical and analytical research approach that is analyzed descriptively. The study results show that the segregated polarization of education for persons with disabilities is contained in Article 10 of Law Number 8 of 2016 concerning Persons with Disabilities and Articles 5, 15 and 32 of Law Number 20 of 2003 concerning the National Education System. The arrangement divides persons with disabilities into particular groups that have an impact on a homogeneous social environment. Therefore, the ideal design is educational equality, as in the United States, where people with disabilities attend regular schools. Besides that, it is necessary to have equal education for people with disabilities in the laws and regulations in Indonesia.
\end{abstract}




\section{Introduction}

Imagine and designing the future is human instinct. An utopia is a radical form of vision that is understood as the "future goals" of the reality of the desired future. Utopia arises when people think outside the system's limitations or the current situation about the current action and future. Utopia breaks the limits of the rational and, at the same time, delivers the ideal image of society inspired by its creators' values. Utopia tends to be criticized as not valuable because it does not seem realistic or even dangerous. However, according to Savage, rejection of utopia is a limitation of thought, Saage said that: ${ }^{1}$

"Anyone who equates the future with a view of the present does not require a utopia anything. Anyone who saw the future, which is characterized by an open horizon, should define how the world we want to live tomorrow that can only be answered with utopian thinking."

Utopian thinking can often be seen as a way of dreaming and fantasizing about a perfect world with all the goodness in it. In the thinking behind the law and legal system, the imagination underlies the world of law ideal. In the book "the Law and the Utopian Imagination", by Austin Sarat, Lawrence Douglas and Martha Merrill Umphrey, as well as "Every day The Conceptual Life of Promising Spaces Utopias" of works Davina Cooper that draw utopia law as the ethic, the way, the concept of process-oriented hope, desire, and belief in the possibility of the perfection of the law. ${ }^{2}$

One of the desires of utopia, the most important law, is equality for all and without discrimination. The right to education is a thing to be owned by any human being or citizen as far as we understand that education is an effort in helping the development of the human to be more forward in the development of the academic and the image

\footnotetext{
1 Hensler, L., Mercon, J., and Vilsmaier, U. "Diverse Values and a Common Utopia: Insights from a Participatory Art-Based Plural Valuation Experience in Xalapa, Mexico". Case Studies in the Environment, 5 (1), 2021, p. 2

2 Cooper, D. (2014). Everyday Utopias: The Conceptual Life of Promising Spaces, Durham: Duke University Press, p. 3
} 
as a social creature that can live in the environment. ${ }^{3}$

The implementation of national education is based on the different laws, following the nature of philosophy of each country. However, the difference is the philosophical basis that applies universally in every country, that is to say, a fundamental duty for any country. To carry out their national education, every citizen as a human being has the right and obligation to obtain an education. ${ }^{4}$

Indonesia's constitution explicitly confirms that education is a human right guaranteed in Article 31 paragraph (1) Indonesian Constitution of 1945U states that "Every citizen has the right to education". Therefore, it is the duty of the state, both central and local government, to provide access areas for all citizens, including persons with disabilities.

The law of disability itself centrally concerns the role of law in creating, preserving, against discrimination of persons with disabilities, which becomes essential with depth implications for social justice. The right to education Disabilities still experiences severe problems because it is considered a disability is considered adverse, the presence of exclusion and marginalize people with disabilities. It is based on the view that persons with disabilities have the distinction of body/mind deviate from the norm 'ability which is generally accepted from the physical, sensory, cognitive, neurological function, or emotional. ${ }^{5}$

The above problems have become international attention with penges Convention on the Rights of Persons with Disabilities (CRPD) in 2008,6 in is human rights instruments to protect the rights of people with disabilities that contains the 8 principles of the framework guidelines of the CRPD that found in the general

\footnotetext{
3 Direktorat Jenderal Pendidikan Tinggi. (2012). Panduan Pelayanan Pendidikan bagi Mahasiswa Penyandang Disabilitas di Perguruan Tinggi. Jakarta: Direktorat Jendral Pendidikan Tinggi. p. 1

4 Suhartono, S. (2008). Wawasan Pendidikan (Sebuah Pengantar Pendidikan). Yogyakarta: Ar Ruz Media. p. 82

5 Lawson, A. and Priestley, M. (2017). The Social Model of Disability: Questions for Law and Legal Scholarship? Routledge Handbook of Disability Law and Human Rights, eds P. Blanck and E. Flynn. p. 3

${ }^{6}$ State Sheet of the Republic of Indonesia of 2011 Number 107 and Explanation on Supplement to State Sheet of the Republic of Indonesia Number 5251
} 
principles in Article 3, namely: ${ }^{7}$

1. Respect for inherent dignity, individual autonomy, including the freedom to make his own choices, and freedom of the people

2. Non-discrimination

3. Participation and full inclusion and effectiveness in the community

4. Respect for difference and acceptance of persons with disabilities as part of human diversity and humanity

5. Equality of Opportunity

6. Accessibility

7. Equality between man and woman

8. Respect the capacities of children with disabilities, and continue to evolve and respect for the rights of children with disabilities to preserve their identities

Under the CRPD, disability is seen as an aspect of social diversity, not as a medical condition that needs help. So, experts argue that the Convention adopted the social model against people with disabilities and introduced the paradigm and the new model against people with disabilities. The CRPD itself is opened by points (h) confirming that discrimination against people with disabilities violates dignity and inherent value. Article 24 of the UN Convention on the Rights of Persons with Disabilities (CRPD) protect the right to education of persons with disabilities, which states the right to inclusive education and determine the steps that should be taken for inclusive education for persons with disabilities. Article 24 of the CRPD provides that persons with disabilities should not be discriminated against, but more than those persons with disabilities should be able to participate and engage fully in the design of the Education system.

Indonesia is still segregated as a country that has ratified the CRPD in education programmed for persons with disabilities. While the mandate of the CRPD is that the

\footnotetext{
${ }^{7}$ Compare with Chiluba, B. C. "Barriers to Health Care for Disabled People: A Review of the Literature from Low-Income Countries”. Indonesian Journal of Disability Studies (IJDS), Vol. 6(2), 2019. p. 210.
} 
Pattern of education for persons with disabilities is inclusive with the integration of the regular education with special education in the education system to accommodate the differing needs of students, but the Pattern of inclusive education is not yet in actualizing on the National Education system. This can be seen in article 5, paragraph 2, which suggests that: "citizens who have abnormalities in physical, emotional, mental, intellectual, or social, are entitled to special education". Furthermore, article 15 of the same Legislation states that "the Type of education includes general education, vocational, academic, professional, vocational, religious, and special". Article 32 asserted special education is 'education for learners who have a level of difficulty in following the learning process because of abnormalities in physical, emotional, mental, social, and have the potential for intelligence and special talent'

The provisions of article 5, article 15 and article 32 of the LAW on national education show that there are still groups of different specials with learners regular. It confirms that the orientation of education tends to be "segregation", as in the Education ACT, has not been clearly or completely put forward the norm of 'inclusive education'. Therefore, the existence of a model of education segregation is contrary to the model of inclusive education. The principle to provide access to a comprehensive education for persons with disabilities will be challenging to achieve because not all schools accept students with special needs.

The term "special education", as stated in the quoted article 32 paragraph 1 of the LAW of national Education, can be interpreted as inclusive education half-hearted because the model implementation of inclusive education has to adjust to the peculiarities of learners with special needs does not mean the implementation of education is equated with the model of education segregation.

See Education LAW can be said to have not been set explicitly the norm leads to the Pattern of organization of education for persons with disabilities an inclusive, progressive, although can understand this is to accommodate the unique needs experienced by learners with disabilities will be but the Pattern segregated row open space discriminatory because of the difference in treatment to obtain the right to education. The state gives the polarization of the persons with disabilities the option to choose while learners who are non-disabled are free to choose to study. When 
people with disabilities want to go to school in the regular school does not be directly on the receipt. However, the school can refuse based on disability to have a particular school, but non-disability is the opposite. Therefore unwittingly, countries participating in the polarizing education for persons with disabilities is discriminatory and injure the constitutional mandate of Article 31 of the Constitution of 1945.

It specifically has an impact on the education gap that still be an essential issue for persons with disabilities this is because most of the people with disabilities dominate in the low education levels, namely $25,83 \%$ Elementary School and equivalent, $30,54 \%$ did not complete primary school, and some even have never been to school as much as $21,22 \%$. While completing his education up to the college level is only $2.8 \% .^{8}$ See the data; the decline in participation of persons with disabilities with the ever-increasing level of education shows pattern segregation. This did bring a significant impact on every stratum of education.

If observed further, the persistence of education segregation for persons with disabilities leads to discrimination implicitly escort stigma. ${ }^{9}$ That disability a place for education is the school unique and not the school regularly. This setting, although in practice, still provides access to education to people with disabilities but implicitly limits the social environment that impacts the lack of self-confidence to hang out with no disabilities. Therefore, it is necessary to provide equal education for persons with disabilities to attend school in regular school.

\section{Problem Statement}

Based on the above explanation, the strong Pattern of education segregation in Indonesia on the education of persons with disabilities impacts the disparity of

\footnotetext{
8 Badan Pusat Statistik (BPS). (2019). Potret Pendidikan Statistik Pendidikan Indonesia 2019. Jakarta: BPS. p. 84

${ }_{9}^{9}$ About the stigma of people with disabilities, Paul Longmore himself explained that: "The Stigma is produced through the dynamic interaction of the constellation of factors that complicated that includes stigmatizing not only physical and mental limitations and the physiological but also the physical environment, social settings, cultural values, and the impact of public policy itself... Disability is not a thing that remains, but one elastic thing and the category of the social dynamic. This is not an objective condition, but a set of social identity produced for social change, as well as developing historically", Longmore, P. (2003). Why I Burned My Book and Other Essays on Disability. Philadelphia: Temple University Press. p. 238.
} 
education, stigma, and social environment are limited. Therefore, it is crucial to see how patterns of educational settings disabled disabilities and the ideal setting towards the equality of education of persons with disabilities in Indonesia.

\section{Methods}

This research is categorized into the type of research is a normative legal it is based on the issues and themes raised as a research topic. The research approach used is philosophical and analytics. The research focuses on the view of the rational, analytical, critical and philosophical. It ends with the conclusion that aims to generate new findings as answers from the subject matter that has been set. As well as will be analyzed with a descriptive-analytical method, namely by describing the laws and regulations that apply to the legal theory and practices of law enforcement positively related to the problem. ${ }^{10}$

\section{Discussion}

\subsection{The Philosophy of Utopia}

Sir Thomas More, in his work entitled utopia (1516), is considered as the first person to introduce and popularize the word utopia to describe a perfect world. The word utopia has in common in Greek auto pos, which means the place of "good."11 Thomas More describes his vision of an ideal society in his work, which is almost impossible to find in human life. The word "utopia" is the binary opposition of the word "dystopia. 12" Thomas More, in 1515, wrote about the "Utopia," published in 1516. Portrait of Utopia as the notion of an ideal society that the setting based on "reason." More alone to imagine the vision of the people of an egalitarian based on rationality and arise together. ${ }^{13}$

Utopia in the expansion has become an exciting review among legal experts as has been said by John Rawls about utopia by Rawls, utopia realistic to accommodate the

\footnotetext{
10 Marzuki, P. M. (2011). Penelitian Hukum. Jakarta: Kencana Prenada Media Group. p. 22

11 Sir Thomas More himself stated that: "What we can receive with certainty is that Utopia is full of ideas that worth to be explored and often suggest possible approaches to the solution of problems of social, political, and legal important", Malloy, M. P. "Utopia and the Law and Liter A and the Law and Literature Movement". Pac Law Rev. 1 (2016). p. 7

12 The Greek root word for dystopia is the term Mills which means a wrong place. Ibid.

13 Rosaliza, M., and Syam, E. "Masyarakat Utopis Dan Distopis Dalam Teks the Ones Who Walk Away from Omelas, Karya Ursula Le Guin". Jurnal Ilmu Budaya, Vol. 15, No. 1 Agustus Tahun 2018. p. 14
} 
"fact of pluralism that makes sense" the presence of competition is inevitable, conflicting beliefs, and often cannot be compared and values; only by doing that he can reflect the reality of the human condition. ${ }^{14}$ Expressly in a society offered by More as a model, at least utopian ideal is equality even utopia against discrimination based on physical, especially the physical appearance that is considered not an average human or can be said as a disability. ${ }^{15}$ Where is utopia fighting for the equality of political, economic, and education?

About disability, in the approach utopia, Sara Deutch Schotland states: ${ }^{16}$

"In utopia, individuals with disabilities serves as a critique of where we see the extent to which people with disabilities are respected and treated, or neglected and abused that in perspective "theory of justice" can illuminate our view to utilize disability issues in utopia to criticize or reform institutions."

Based on that approach, a utopia that leads to equality remains a legal issue that is important to be solved, particularly on the education of the disabled. This is solely to solve the problem of the Pattern of educational disabilities that is still segregation.

\subsection{Dystopia Patterns of Educational Arrangements for Persons with}

\section{Disabilities in Indonesia}

The legal basis for the right of education is mandated in Article 28C Paragraph (1) Indonesian constitution of 1945 , which states that:

"Everyone has the right to develop themselves through the fulfilment of basic needs, has the right to education and obtain the benefits of science and technology, art and culture, in order to improve the quality of life and for the welfare of mankind."

The cornerstone of primary education is also regulated in Law Number 20 the Year 2003 about National Education System. Article 1 (1) of the Education ACT states:

${ }^{14}$ Compare with Young, S. P. (2011). Realistic Utopia in Young S. P. (2011). Difference Principle. In Chatterjee D.K. (eds) Encyclopedia of Global Justice. Dordrecht: Springer. p. 930

${ }^{15}$ Compare with Herman, S. "Constitutional Utopianism: An Exercise in Law and Literature". McGeorge L. Rev. 93, 2017. p. 104-105

${ }^{16}$ Compare with Schotland, S. D. (2011). Disability and Disease in Utopian and Dystopian Fiction: Justice and Care Perspectives. Dissertation Faculty of the Graduate School of the University of Maryland at College Park in partial fulfilment of the requirements for the degree of Doctor of Philosophy. p. 16 
"Education is a conscious and planned effort to create an atmosphere of learning and learning process so that learners are actively developing the potential for him to have the spiritual power of purpose, self-control, personality, intelligence, noble character, and skills needed him, society, nation and State."

He stressed on the System of National Education the purpose of education, so peseta students can learn actively to develop their potential in a fair and conscious and obtain all people, including people with disabilities. In line with that, one of the essential principles is a guarantee of equality for all people before the law. Everyone is entitled to recognition, guarantees, protection and certainty of the same law, as well as a fair treatment before the law. The protection of the law for the nation of Indonesia is based on the concept and recognition of the values of human rights, namely Pancasila as the ideology and philosophy of life, which recognizes the dignity of the human person as embodied in the Legislation of the Republic of Indonesia Year 1945. As mentioned earlier, Indonesia's constitution guarantees the right to education, including persons with disabilities with the legal status and rights the same and an integral part of the citizens and the people of Indonesia. It is translated in more explicit in the Law Number 8 of 2016 On Persons with Disabilities, as published in the State Gazette of the Republic of Indonesia Year 2016 Number 69 and explanations on the supplement to the State Gazette of the Republic of Indonesia Number 58712016 (the LAW of Disability). The LAW of Disability states that persons with disabilities are

"Any person experiencing the physical, intellectual, mental, and sensory limitations in a long time that in interacting with the environment can experience obstacles and difficulties to participate fully and effectively with people from other countries based on equality of rights". ${ }^{17}$.

This Legislation own set of the right to education for persons with disabilities in article 10 mentions:

The right to education for Persons with Disabilities includes the right:

\footnotetext{
17 Article 1 of Law Number 8 of 2016 concerning Persons with Disabilities
} 
a. Get quality education in the educational unit in all types, paths, and levels of education in inclusive and particular;

b. Have the same Opportunity to become educators or educators in the educational unit in all types, paths, and levels of education;

c. Have the same Opportunity as the organizer of quality education in the educational unit in all types, paths, and levels of education; and

d. Get a Decent Accommodation as learners.

Understand sentence of article 10 of point a of the ACT Disability, can be said normless clear because it can be understood the implementation of inclusive education is to provide the broadest possible access for all people to acquire quality education and follow the needs without discrimination in order to achieve educational equity, not by separating people with disabilities. ${ }^{18}$ Phrases division for inclusive and special make the pattern of education in the LAW on Disability is still segregated which is defined as the separation (a people from the other faction); exile; exclusion but is inclusive in accordance with its meaning and purpose. ${ }^{19}$

Models of inclusive education for persons with disabilities, as mentioned above, is the merging of regular education with special education in the school system, which are combined to meet the needs of students. However, the inclusive education model is not following the national education system article 5, paragraph 2 , which states that "citizens who have abnormalities in physical, emotional, mental, intellectual, or social, are entitled to special education". Article 15 further states that "this Type of education includes general education, vocational, academic, professional, vocational, religious, and special". Article 32 defines special education as education for learners who have a level of difficulty in following the learning process because of abnormalities in physical, emotional, mental, social, and or has the potential to intelligence and talents.

Article 5, Article 15, and Article 32 of the LAW on the national Education system of

18 Compare with Herawati, N. I. "Pendidikan Inklusif". EduHumaniora, Jurnal Pendidikan Dasar Kampus Cibiru, Juli 2016. p. 2

${ }^{19}$ Kementerian Pendidikan, Kebudayaan, Riset, dan Teknologi Republik Indonesia. Segregasi. Retrieved from https://kbbi.kemdikbud.go.id/entri/segregasi (Accessed on 10 June 2021) 
the above indicates the presence of a particular group, namely the citizens who have the disorder and extraordinary intelligence that requires a particular approach. This suggests the existence of orientation education "segregation" and not "inclusive", as in the Education ACT has not been clearly or a complete set for a particular term "inclusive education". Therefore, there is a model of education segregation, contrary to the model of inclusive education. The principle to continue to provide access to education intact for all people with disabilities will be challenging to achieve the national Education ACT gives space for the school to refuse the learners disabilities.

The term "special education" as stated in article 32, paragraph 1 of the LAW of national Education system cannot be defined with the term inclusive education as a model for inclusive education implementation to adjust with the peculiarities of the learners and their needs and does not mean that the implementation of the special education instead identified with the model of the implementation of educational segregation. Until now, this can be understood that the inclusive education model has not yet become an integral part of our national education system. Implementation of inclusive education at this time, still it can be said that such a rule has not set a precise model of inclusive education progressive for persons with disabilities.

Obscurity between the Pattern of inclusive education and unique is also evident from the settings of learners with disabilities in Government Regulation of the Republic of Indonesia Number 17, 2010 On the Management and Implementation of Education (PP/17/2010) confirms special education for students with disabilities in Article 129, paragraph (3) states that:

"Learners with impairments consists of students who: a. the visually impaired; b. deaf; c. the mute; d. tunagrahita; e. quadriplegic; f. tunalaras; g. difficult to study; h. slow to learn; i. autistic; j. have a motor disorders; k. become a victim of the abuse of narcotics, illegal drugs, and other addictive substances; and l. have other abnormalities."

The explanation above shows that the Pattern of education of persons with disabilities does not yet have legal certainty because the Pattern of inclusive education and special who has different notions of set one thing in common. It 
certainly makes a legal loophole for educational institutions to refuse persons with disabilities because the Education LAW and the LAW of Disability provide a space for the school to direct the school in Sekolah Luar biasa (SLB) as outlined in article 132 and $133 \mathrm{PP} / 17 / 2010$, which is the point to mention students who have abnormalities will be studying in school.

Based on this, it is necessary to conduct the reform of the system of national education of Indonesia that is inclusive to accommodate the participation of students with disabilities by that:

1. The presence of transformation of the Education System

Transformation of education should be carried out with that approach is "education for everyone" regardless of physical, mental and monitoring. The problems of adaptation of educational services for persons with disabilities adjusted with an increase in the quality of educators with a unique program to increase the capacity and capability of educators in providing educational services to people with disabilities.

2. The Vision of People with Disabilities Are Free to Choose Education

For this without even knowing the state involved in performing the discrimination education for persons with disabilities. If we compare it with the features for learners regular, they are free to go to school anywhere, but learners' disabilities given a choice would choose the regular school or the special. Therefore, a fundamental transformation is needed as an answer to the problem is.

3. Revision of the National Education System Law and the Law on Disabilities

The revision of the Education Law and the Law of Disability is absolute to do as part to realize education disabilities in full. The critical thing to do is 1). Eliminate the phrase special education, 2). Affirmation of inclusive education, 3). Requires schools to accept students with disabilities, 4). Provide sanctions for schools that refused learners disabilities, and 5). Requires each school to have educators who can provide the service of education to the learners 
regular and persons with disabilities.

\subsection{Utopia Is the Ideal Setting for Towards the Equality of Education of Persons with Disabilities in Indonesia}

Equality of education in the form of the absolute requires that all students, regardless of ability, be educated in their local schools through the provision of practice, pedagogy, and resources as appropriate. The toppings suggested, "...Equality implies diversity and supports the achievement and participation of all the students who face the challenge of learning and behavior in any form, in terms of the state of socialeconomic, ethnic origin, cultural heritage, religious, linguistic heritage, gender, sexual preference, and education". ${ }^{20}$ Understanding the equality of education is a shift from the roots of special education.

Suppose you see the approach taken by the United States has adopted "multiculturalism" as a principle of national politics. The state is characteristic of the politics of multiculturalism, which aims to "recognize the legitimate interests of minorities in the identity and culture as well as education is one of the persons with disabilities, without compromising the core values of democracy. ${ }^{21}$ It can be seen from the Pattern of education in other countries such as the United States (US) are regulated in the law on the Training of Individuals with Mental Disorders 1995 where the US for school children with disabilities in the join with the regular school at all levels of education where students no longer attend school in particular educational institutions, and persons with disabilities can be overcome problems among friends who are non-disabled. Inclusive schools in the US alone provide a particular service and all appropriate assistance to persons with disabilities. ${ }^{22}$

See the Pattern of education in Indonesia service inclusive only in the limit to the level of primary and secondary education as outlined in article 4 paragraph 1 of the Regulation of the Minister of National Education Republic of Indonesia No. 70 of 2009

20 Compare with Topping, K. (2012). "Conceptions of inclusion: Widening ideas". in Boyle, C., and Topping, K. (Eds.). What works in inclusion? Berkshire: Open University Press. p. 19

${ }_{21}$ Compare with Ijaz, N., and Boon, H. "Medical Pluralism and the State: Regulatory Language Requirements for Traditional Acupuncturists in English-dominant Diaspora Jurisdict". SAGE Open April-June, 8(2), 2018. p. 4

${ }^{22}$ Compare with Grynova, M., and Kalinichenko, I. "Trends in Inclusive Education in The USA And Canada". Journal Comparative Professional Pedagogy, 8 (2), 2018. p. 30 
About the Inclusive Education for Learners with disabilities And Has the Potential Intelligence And/Or Special Talent (Permendiknas/70/2009)23.

The issue of substance in the rules of some of the laws above have implications on the implementation. The role of government and/or state in pursuing education for persons with disabilities is not maximized, which is quite alarming if disabled if you want to study to be together with friends who share the same fate. The state approves or permits the application of the policy for people with disabilities to move away from human life in general. This effort is labelled with the term "Sekolah Luar Biasa (SLB)", which is essentially the exclusion or exclusivity. In addition, regular education also tends to refuse students with disabilities. ${ }^{24}$

During this time, many persons with disabilities were "forced" to sign in to excellent schools. School in SLB is not his choice. Several factors cause it. First, the persistence of misunderstanding the perception of people with disabilities as people who have special needs, in the end, people with disabilities at the point in school, although there is a command of the LAW to persons with disabilities attend regular schools. Second, since the beginning, there has been no adequate assessment for Persons with Disabilities to be educated, for example, to ascertain whether people with Disabilities can only learn in a Special School and also whether there is an interest and ability in future to continue to a higher education Third, the lack of regular school to provide educational services to persons with disabilities (in the form of rejection of people with disabilities, facilities/infrastructure that does not support, social environment that is not friendly).

Condition evaluation of the implementation of inclusive education in Indonesia had not yet become urgent to discuss in various forums related to the government's policy towards people with disabilities. Generally, shows the presence of obstacles in the

\footnotetext{
${ }^{23}$ District/city governments appoint at least 1 (one) elementary school, and one (1) secondary school in each district and one (1) unit of secondary education to organize inclusive education are required to accept students as referred to in Article 3 paragraph (1).

${ }^{24}$ As experienced Endang, residents of Sleman. He admitted, his son with special needs was rejected to enrol in one of the JUNIOR high schools in Sleman. The reason the school is not able to and not ready to accept students with special needs. Radar Jogja. Calon Siswa Ditolak Karena Difabel. Retrieved from https://radarjogja.jawapos.com/2019/07/03/calon-siswa-ditolak-karena-difabel/ (Accessed on 10 June 2021)
} 
implementation of inclusive education, among others, the quality of human resources, including teachers and technical learning in the classroom. ${ }^{25}$

Related to the explanation above, aspects of the rights of persons with disabilities has not yet been set in concrete in the national Legislation at this time, including access to education, the structure of which is still hampered by discrimination. Indeed, participation in developing and access to fair rights is still very rarely felt by people with disabilities. The perspective of fairness and physical and spiritual health requirements has alienated the creativity, passion, hopes and aspirations of people with disabilities, even eliminating the inclusive spirit. Therefore, the reform of the education system and approach towards persons with disabilities in education is an obligation that must be done as a mandate from the 1945 constitution.

\section{Conclusion}

Based on the arguments above can be concluded that the system of education for persons with disabilities is still segregated it can be seen from Article 10 of the Law No. 8 of 2016 On Persons with Disabilities and Article 5, 15 and 32 of Law Number 20 of 2003 about National Education System. In the second act, there is still the separation of groups between persons with disabilities and learners in general. It is, therefore, necessary to design, among others: First, a mechanism is needed in the education of persons with disabilities based on equality with convergency schools and special schools. Second, Policies that shaped the government's attitude in support of the implementation of education for persons with disabilities, especially stakeholders in education.

\section{References}

\section{Books}

Badan Pusat Statistik (BPS). (2019). Potret Pendidikan Statistik Pendidikan Indonesia 2019. Jakarta: BPS.

Boyle, C., and Topping, K. (Eds.). What works in inclusion? Berkshire: Open University Press.

\footnotetext{
25 Compare with Pusat Studi dan layanan Difabel UIN Sunan Kalijaga. (2011). Menuju Inklusi: Naskah Akademik Perda Penyandang Disabilitas Yogyakarta. Yogyakarta: UIN Sunan Kalijaga. p. 39
} 
Cooper, D. (2014). Everyday Utopias: The Conceptual Life of Promising Spaces, Durham: Duke University Press.

Direktorat Jenderal Pendidikan Tinggi. (2012). Panduan Pelayanan Pendidikan bagi Mahasiswa Penyandang Disabilitas di Perguruan Tinggi. Jakarta: Direktorat Jendral Pendidikan Tinggi.

Lawson, A. and Priestley, M. (2017). The Social Model of Disability: Questions for Law and Legal Scholarship? Routledge Handbook of Disability Law and Human Rights, eds P. Blanck and E. Flynn.

Longmore, P. (2003). Why I Burned My Book and Other Essays on Disability. Philadelphia: Temple University Press.

Marzuki, P. M. (2011). Penelitian Hukum. Jakarta: Kencana Prenada Media Group.

Pusat Studi dan layanan Difabel UIN Sunan Kalijaga. (2011). Menuju Inklusi: Naskah Akademik Perda Penyandang Disabilitas Yogyakarta. Yogyakarta: UIN Sunan Kalijaga.

Schotland, S. D. (2011). Disability and Disease in Utopian and Dystopian Fiction: Justice and Care Perspectives. Dissertation Faculty of the Graduate School of the University of Maryland at College Park in partial fulfilment of the requirements for the degree of Doctor of Philosophy.

Suhartono, S. (2008). Wawasan Pendidikan (Sebuah Pengantar Pendidikan). Yogyakarta: Ar Ruz Media.

Young S. P. (2011). Difference Principle. In Chatterjee D.K. (eds) Encyclopedia of Global Justice. Dordrecht: Springer

\section{Journal Article}

Chiluba, B. C. "Barriers to Health Care for Disabled People: A Review of the Literature from Low-Income Countries". Indonesian Journal of Disability Studies (IJDS), Vol. 6(2), 2019.

Grynova, M., and Kalinichenko, I. "Trends in Inclusive Education in The USA And Canada". Journal Comparative Professional Pedagogy, 8 (2), 2018.

Hensler, L., Mercon, J., and Vilsmaier, U. "Diverse Values and a Common Utopia: Insights from a Participatory Art-Based Plural Valuation Experience in Xalapa, Mexico". Case Studies in the Environment, 5 (1), 2021

Herawati, N. I. "Pendidikan Inklusif”. EduHumaniora, Jurnal Pendidikan Dasar Kampus Cibiru, Juli 2016.

Ijaz, N., and Boon, H. "Medical Pluralism and the State: Regulatory Language Requirements for Traditional Acupuncturists in English-dominant Diaspora Jurisdict”. Open April-June, 8(2), 2018. 
Malloy, M. P. "Utopia and the Law and Liter A and the Law and Literature Movement". Pac Law Rev. 1 (2016).

Rosaliza, M., and Syam, E. "Masyarakat Utopis Dan Distopis Dalam Teks the Ones Who Walk Away from Omelas, Karya Ursula Le Guin”. Jurnal Ilmu Budaya, Vol. 15, No. 1 Agustus Tahun 2018.

Herman, S. "Constitutional Utopianism: An Exercise in Law and Literature". McGeorge L. Rev. 93, 2017.

\section{Official Web}

Kementerian Pendidikan, Kebudayaan, Riset, dan Teknologi Republik Indonesia. Segregasi. Retrieved from https://kbbi.kemdikbud.go.id/entri/segregasi (Accessed on 10 June 2021)

Radar Jogja. Calon Siswa Ditolak Karena Difabel. Retrieved from https://radarjogja.jawapos.com/2019/07/03/calon-siswa-ditolak-karenadifabel (Accessed on 10 June 2021) 